\title{
Galeri Seni RuPa KiWARI Di Surakarta
}

\author{
Radityo Aryanto, Rachmadi Nugroho, Mohamad Muqoffa \\ Program Studi Arsitektur \\ Fakultas Teknik \\ Universitas Sebelas Maret Surakarta \\ Email : raayoritoo@gmail.com
}

\begin{abstract}
Designing a Contemporary Art Gallery is considered by the rapid development of the art world, and contemporary art is part of the development which has great potential and practice in Surakarta, but the lack of facilities such as a gallery to display contemporary art. The purpose to be achieved is to design a gallery which is able to accommodate contemporary art and its development, to increase the appreciation of contemporary art, the quality of the artists, and the produced works of art. The method to be used is a method of architectural design. The main issues to be solved are: to choose and design the site as required location, the land use of Surakarta, and to be able to support the activities of contemporary art; to design spaces with the display systems which can answer the need of various contemporary art such as painting, printmaking, sculpture, video art, installation art, and environmental art. The result to be obtained is an art gallery which be able to display contemporary art in various forms and presentation, with the design of the building which is also contemporary, so that it can represents the works of contemporary art itself.
\end{abstract}

Keywords: Gallery, Art, Contemporary, Display Rooms, Display, Surakarta

\section{PENDAHULUAN}

Dalam perkembangan pada dunia seni, muncul aliran seni kiwari sebagai refleksi fenomena sosial yang menunjukkan kondisi kreatif pada masa terakhir. Masyarakat pada jaman sekarang menganggap kesenian klasik/tradisional sudah tidak relevan dan membosankan, karena adanya "gap" atau perbedaan pola pikir dan cara masyarakat memandang dan menjalani hidupnya (Lim, 1998). Hal inilah salah satu alasan yang mulai memunculkan aliran seni kiwari.

Merancang untuk seni kiwari melibatkan cara-cara baru dalam mengamati dan berinteraksi dengan seni (Chiara, 2001). Sebagai contoh, dalam hal dimensinya yang sangat beragam, setting ruang terkait dengan penyajian objek pamer, baik membutuhkan pencahayaan pada objek atau tidak, di dalam atau di luar ruang, digantung ataupun free standing.

Praktek berkegiatan seni rupa kiwari di Surakarta sebenarnya cukup produktif. Hal tersebut ditandai dengan kegiatankegiatan pameran dan kegiatan-kegiatan pendukung lain, semakin berkembangnya komunitas-komunitas seni rupa kiwari oleh seniman-seniman muda yang berakar dari institusi pendidikan seni yang ada di Surakarta bersamaan dengan munculnya ruang-ruang berkesenian baru namun dalam skala yang lebih kecil diantaranya adalah Kepatihan Art Space dan Lokananta Art Space.

Dalam ranah seni rupa kiwari, Surakarta masih menjadi kota yang jauh dari rerasan dibanding dengan kota lain di Jawa Tengah seperti Wonosobo dan Semarang (Susanto, 2012). Apalagi jika harus dibandingkan dengan Jogja, Bandung, Surabaya, Bali dan Jakarta. Infrastruktur berupa galeri-galeri yang saat ini ada di Surakarta juga belum cukup ideal untuk mewadahi seni rupa kiwari karena memang tidak dirancang dari awal sebagai sebuah galeri seni rupa kiwari (wawancara dengan Narsen Afatara, 2015).

Kota Surakarta memiliki potensi besar berupa kekayaan kesenian dan budaya yang telah mengakar dalam kehidupan masyarakat. Menururt Narsen 
Afatara, semakin besar kekayaan kesenian dan kebudayaan suatu bangsa atau daerah, semakin besar dan luar biasa pula seni kiwari untuk dikembangkan. Seiring berjalannya waktu, kota Surakarta telah menjadi tuan rumah bagi event budaya tahunan bertaraf internasional seperti SIEM, SIPA, SBC.

Dilihat pada skala yang lebih luas, pada era pemerintahan yang baru ini, ekonomi kreatif semakin digaungkan dan mendapat keseriusan dari pemerintah dengan dibentuknya badan ekonomi kreatif di mana seni rupa merupakan salah satu dari 16 subsektor yang akan ditangani. Hal ini menjadi peluang yang besar bagi perupa dan pemerintah kota Surakarta untuk bersinergi dalam mengembangkan seni rupa kiwari sehingga dapat menjadi daya tarik wisata baru selain seni pertunjukan yang telah menjadi ikon kota Surakarta.

Dengan adanya Galeri Seni Rupa Kiwari yang direncanakan, diharapkan dapat menjembatani antara seniman/perupa kiwari dengan masyarakat luas, serta semakin menggairahkan dunia seni rupa kiwari Indonesia pada umunya dan Surakarta pada khususnya .

\section{METODE}

\subsection{Macam dan Teknik Pengumpulan Data}

1. Data mengenai seni rupa kiwari didapat melalui website, buku, dan wawancara dengan seniman.

2. Data mengenai kondisi galeri yang ada di kota Surakarta dan preseden diperoleh melalui survey lokasi, wawancara dengan seniman, dan website.

3. Data mengenai peraturan tata guna lahan kota Surakarta diperoleh melalui data instansional pemerintah kota.

\subsection{Metode Analisis Data}

Analisis perencanaan (building concept) mengidentifikasi masalah yang ada berdasarkan konsep desain Galeri Seni Rupa Kiwari di Surakarta.

Analisis perancangan (building criteria) dilakukan dengan mengolah data-data yang telah terkumpul dan dikelompokkan berdasarkan pemrograman fungsional, performansi, dan arsitektural.
1. Program fungsional untuk mengidentifikasi penggunaan pada Galeri Seni Rupa Kiwari, di antaranya adalah pelaku kegiatan, jenis kegiatan, pola kegiatan, sifat kegiatan dan sifat organisasi.

2. Program performansi untuk menentukan secara sistematik kebutuhan para pengguna Galeri Seni Rupa Kiwari beserta fasilitasnya ke dalam persyaratan pemilihan tapak, persyaratan ruang, persyaratan besaran ruang dan program ruang.

3. Analisis arsitektural merupakan tahap penggabungan dari hasil identifikasi program fungsional dan performasi. Proses ini dilakukan dengan cara menganalisa tapak, massa, peruangan, tampilan bangunan, utilitas dan struktur.

Tahapan selanjutnya adalah tahap sintesis, yaitu penggabungan dari referensi dan hasil analisa fakta lapangan sehingga akan mendapatkan kesimpulan untuk memperolah konsep perancangan yang kemudian akan ditransformasikan ke bentuk Galeri Seni Rupa Kiwari yang diinginkan.

\section{ANALISIS}

\subsection{Analisis Peruangan}

1. Tujuan: Memperoleh jenis kebutuhan ruang.

2. Pertimbangan: pengelompokan kegiatan dan pelaku kegiatan.

3. Hasil analisis: pelaku kegiatan pada Galeri Seni Rupa Kiwari adalah:
a. Pengunjung
b. Seniman
c. Pengelola

Berikut adalah kebutuhan ruang dan total luasan ruang yang dibutuhkan:

a. Kegiatan utama: ruang pamer tetap dan temporer, penyimpanan karya.

Total uasasn: $3436,35 \mathrm{~m}^{2}$

b. Kegiatan pendukung: studio seniman, kelas workshop, wisma seniman, ruang serbaguna, perpustakaan, amphiteater. Total luasan: $1691 \mathrm{~m}^{2}$

c. Kegiatan komersial: art shop dan coffee shop.

Total luasan: $278,81 \mathrm{~m}^{2}$ 
d. Kegiatan pengelolaan: ruang direktur, manajer, koordinator, kurator, ruang rapat, dan arsip.

Total luasan: $151,3 \mathrm{~m}^{2}$

e. Kegiatan servis: musholla, lavatory, loading dock, ruang mekanikal elektrikal, parkir pengunjung dan pengelola.

Total luasan: $1.066,56 \mathrm{~m}^{2}$

\subsection{Analisis Terkait dengan Seni Rupa \\ Kiwari}

1. Tujuan: memperoleh setting ruang yang memenuhi tuntutan seni rupa kiwari.

2. Pertimbangan: kenyamanan pandang pengunjung, penyajian materi pameran, batas pandang atas, tata pencahayaan.

3. Hasil analisis:

a. Ruang pamer menggunakan bentuk dasar persegi yang lebih fleksibel dalam pengolahan ruang dan penyajian materi pameran karyakarya seni rupa kiwari.

b. Untuk mewadahi keberagaman bentuk, dimensi, dan media dalam seni rupa kiwari, disediakan ruang pamer dengan ketinggian yang bervariasi antara $\pm 3 \mathrm{~m}$ hingga $\pm 7 \mathrm{~m}$ yang diperoleh melalui perhitungan batas pandang atas dan penggunaan standar untuk ruang pamer seni rupa kiwari.

c. Ruang-ruang pamer bersifat netral tanpa ornamentasi, karena setiap elemen pembentuk ruang dapat dijadikan background dan media dalam berkarya.

d. Ruang-ruang pamer didesain untuk memungkinkan pengunjung dapat melakukan pengamatan karya secara vertikal melalui void dan/tangga, sehingga dapat diperoleh sudut pengamatan yang lebih bervariasi.

e. Setting ruang terkait dengan penyajian materi pameran (lihat Gambar 1).

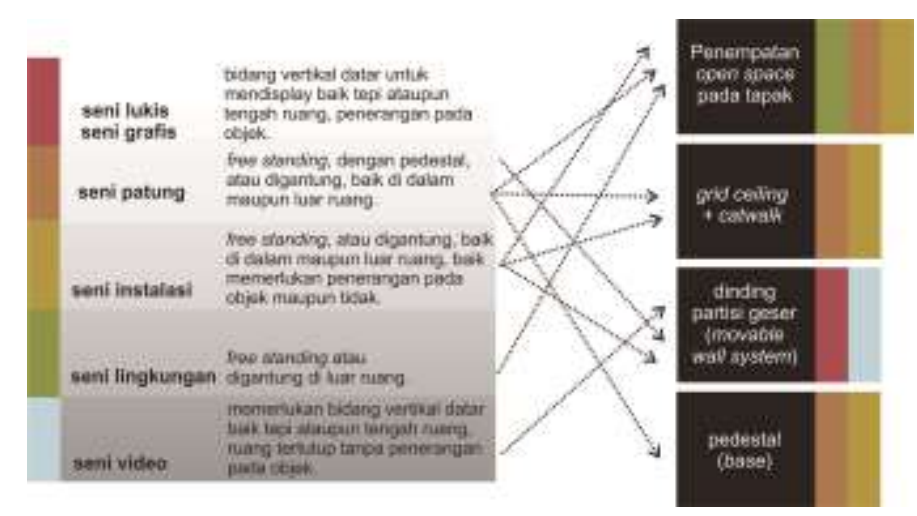

Gambar 1. Setting Ruang dan Penyajian Materi Pameran

1) Penempatan open space pada tapak. Area pada timur tapak dapat digunakan untuk karya-karya yang memang bersifat lebih publik, untuk menarik keingintahuan masyarakat. Sedangkan area pada sisi barat tapak dan ruang-ruang terbuka pada atap untuk jenis-jenis karya yang lebih membutuhkan suasana yang tenang dan jauh dari keramaian (lihat Gambar 2).

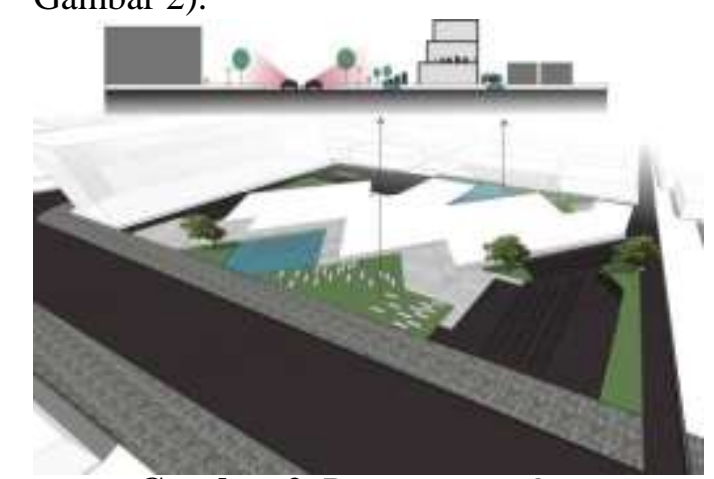

Gambar 2. Penempatan Open Space Pada Tapak

2) Dinding partisi geser (moveable wall system)

Bagi seni lukis dan grafis dapat yang memerlukan

bidang vertikal datar menjadi backgorund. Selain itu untuk karyakarya seperti seni video dan beberapa karya instalasi yang tidak memerlukan penerangan pada objek, dapat digunakan untuk membentuk setting ruang yang tertutup (lihat Gambar 3). 


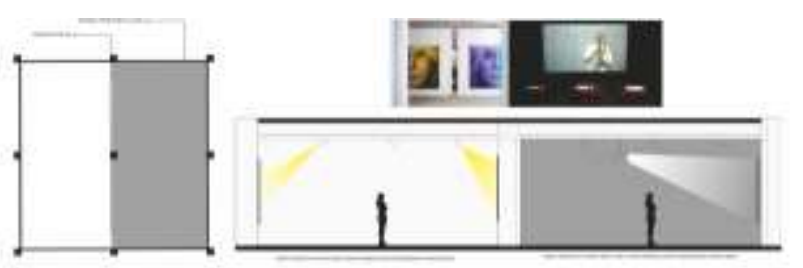

Gambar 3. Penggunaan Dinding Partisi Geser

3) Grid metal ceiling dan catwalk

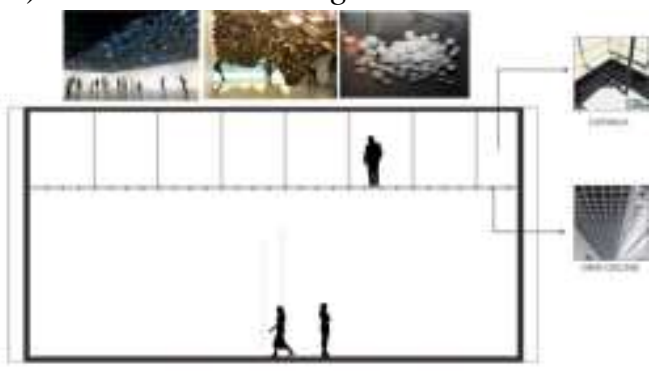

Gambar 4. Penggunaan Grid Ceiling dan Catwalk

Penggunaan grid ceiling dan catwalk terutama ditujukan untuk karyakarya seperti instalasi dan patung yang dipamerkan dengan penyajian gantung sehingga dapat lebih fleksibel dalam penempatan, pengaturan ketinggian, dan mengubah sorot penerangan pada objek (lihat Gambar 4).

4) Pedestal (base)

Penggunaan pedestal ditujukan untuk menunjang kenyamanan pandang sehingga pengunjung tidak terlalu menunduk dalam mengamati karya seni rupa kiwari yang berdimensi kecil (lihat Gambar 5).
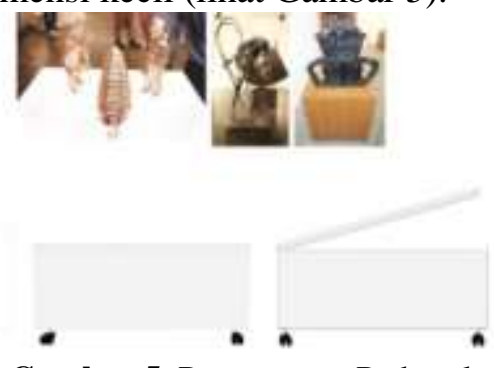

Gambar 5. Penggunaan Pedestal

\subsection{Analisis Penentuan Tapak}

1. Tujuan: mendapatkan lokasi yang sesuai dan mendukung sebagai area didirikannya bangunan.

2. Pertimbangan: aksesibel, lokasi strategis, memiliki lahan yang cukup luas, tidak menyalahi peraturan pemerintah yang berlaku.

3. Hasil analisis: tapak terpilih berada di kawasan Ngarsopuro. Tapak berada di Jl. Diponegoro dengan luas $5.335 \mathrm{~m}^{2}$. Tapak berbatasan dengan pemukiman pada sisi barat, Jl. Diponegoro pada sisi timur, Jl. Madura pada sisi utara, jalan lingkungan dan ruko pada sisi selatan (lihat Gambar 6).

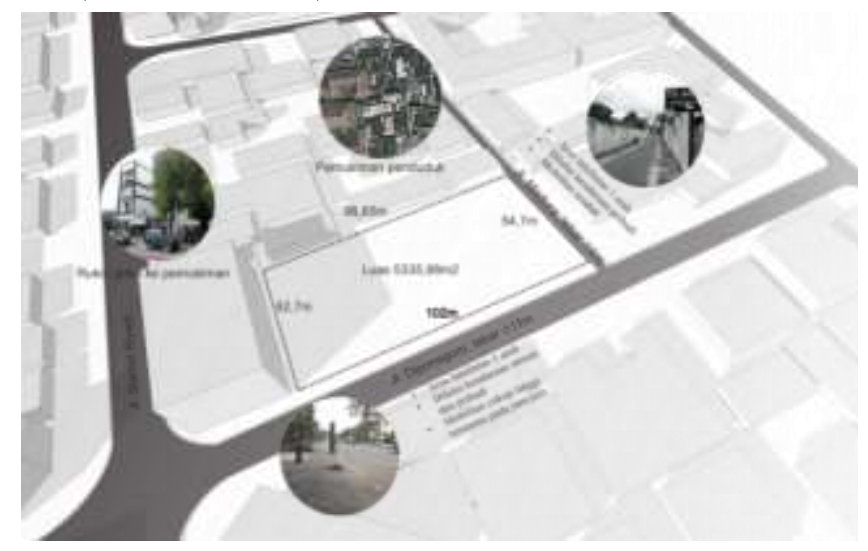

Gambar 6. Batas-Batas Tapak

\subsection{Analisis Pencapaian}

1. Tujuan: menentukan letak main entrance dan side entrance.

2. Pertimbangan: kondisi dan potensi jalan di sekitar area tapak, sirkulasi yang jelas dan mudah dicapai, keamanan dan kenyamanan sirkulasi tanpa crossing antar pengguna.

3. Hasil analisis:

\section{a. Kendaraan bermotor}

Main entrance diperuntukkan bagi pengunjung yang berkendaraan pribadi yang terdiri dari motor dan mobil, untuk menghindari kemacetan pada perempatan jalan Slamet Riyadi, main entrance ditempatkan agak jauh dari titik tersebut, yaitu pada sisi utara tapak. Sedangkan side entrance diperuntukkan bagi pengelola dan kegiatan loading dock sifatnya temporer, maka side entrance ditempatkan pada sisi timur tapak (lihat Gambar 7).

b. Pejalan kaki

Akses bagi pejalan kaki dapat dicapai langsung pada bagian tengah tapak Jl. Diponegoro dan Jl. Madura yang tidak bersinggungan dengan akes 
kendaraan baik pengunjung, pengelola dan servis (lihat Gambar 7).

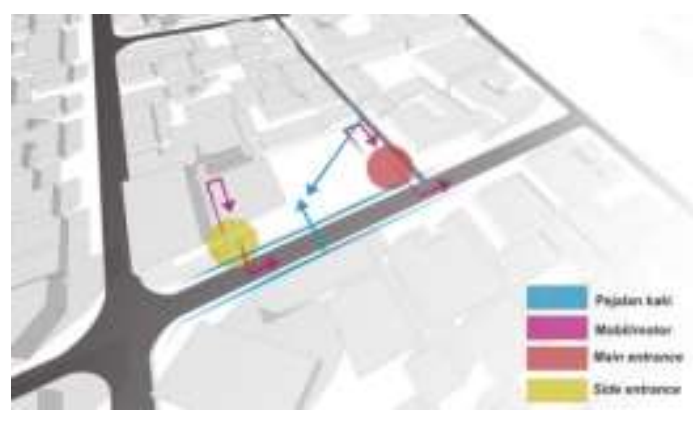

Gambar 7. Entrance Pada Tapak

3.5 Analisis Pemintakatan (Zoning)

1. Tujuan: mendapatkan lokasi yang sesuai dan mendukung sebagai area didirikannya bangunan.

2. Pertimbangan: sifat kegiatan, kedekatan hubungan antar kelompok kegiatan, studi preseden.

3. Hasil analisis: zona utama yang terdiri dari ruang-ruang pamer dan penyimpanan karya sebagai pusat kegiatan ditempatkan pada bagian tengah tapak. Zona penunjang yang bersifat semi publik diantaranya perpustakaan, ruang serbaguna, studio seniman, ditempatkan pada sisi utara tapak yang berhubungan erat dengan zona utama. Zona komersial ditempatkan pada bagian depan tapak sehingga dapat diakses oleh pengunjung tanpa memasuki area lain pada galeri. Zona pengelolaan yang membutuhkan tingkat keprivasian lebih ditempatkan pada bagian barat tapak atau lantai atas. Zona servis yang berupa area parkir berada pada bagian depan tapak sisi utara dan selatan. Sedangkan ruangruang servis lain yang berupa ruang utilitas dan sejenisnya ditempatkan pada area basement (lihat Gambar 8).

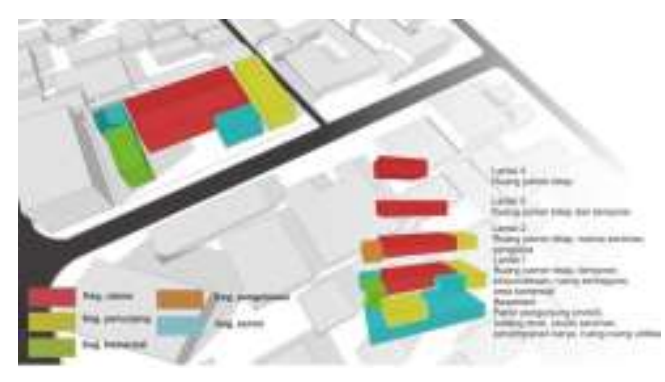

Gambar 8. Pemintakatan Bangunan

\subsection{Analisis Tata Massa}

1. Tujuan: menentukan pola tata massa yang dapat menunjang fungsi bangunan

2. Pertimbangan: dinamis dalam hal pergerakan (sirkulasi) dan komposisi massa, hasil analisis pemintakatan.

3. Hasil analisis: pola tata massa yang digunakan adalah pola tata massa gabungan yang memberikan kesan yang dinamis dalam hal susunan massa dan pergerakan (sirkulasi) yang selanjutnya akan disatukan menjadi satu kesatuan. Massa bangunan secara garis besar dapat dibagi menjadi massa bangunan utama dan penunjang (lihat Gambar 9).

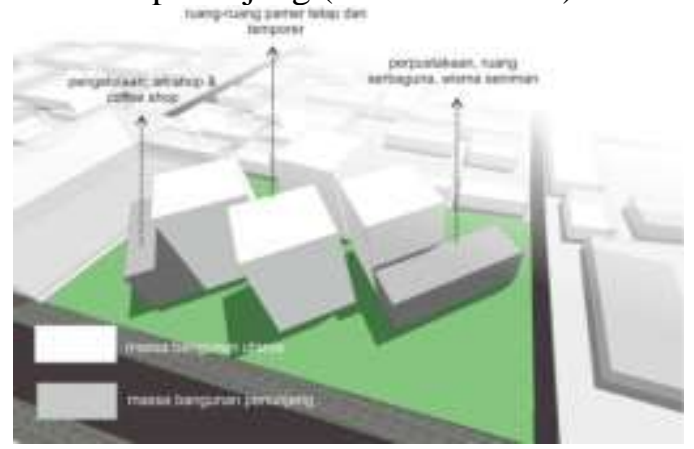

Gambar 9. Pola Tata Massa

\subsection{Analisis Gubahan Massa}

1. Tujuan: menemukan gubahan massa yang sesuai dengan kebutuhan serta karakter bangunan.

2. Pertimbangan: fleksibel, Dinamis, Kiwari

3. Hasil analisis: gubahan massa menggunakan bentuk dasar persegi yang lebih fleksibel dalam pengolahan yang selanjutnya dikembangkan sehingga lebih mewakili seni rupa kiwari dan dapat lebih menunjang fungsi bangunan (lihat Gambar 10). 

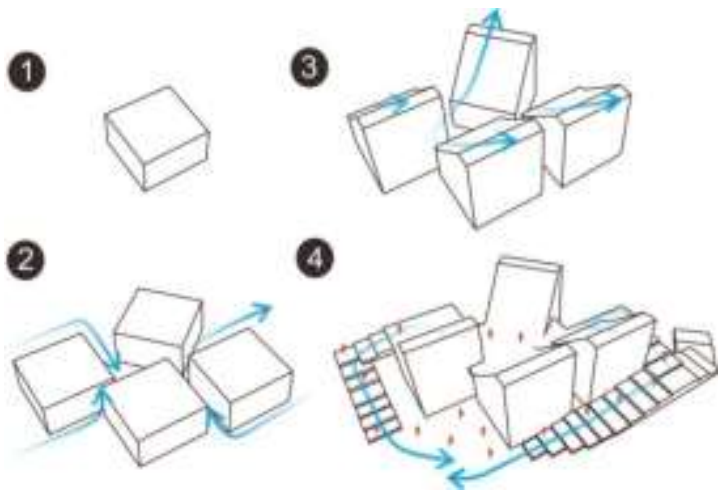

Gambar 10. Eksplorasi Bentuk

Bentuk yang menjulang ke atas menggambarkan semangat perubahan dan kebaruan dari seni rupa kiwari yang dinamis. Sedangkan bentuk yang menerus dari tapak merupakan perluasan open space pada tapak yang dapat digunakan untuk menggelar pameran temporer outdoor (lihat Gambar 10).

\subsection{Analisis Tampilan Bangunan}

1. Tujuan: menentukan tampilan bangunan yang dapat menunjang fungsi bangunan.

2. Pertimbangan: karakter seni rupa kiwari, penyajian karya.

3. Hasil analisis: permainan garis pada bidang fasad sebagai secondary skin, untuk mengurangi kesan massif pada bangunan. Pada massa utama, kulit bangunan sekaligus dapat dijadikan sebagai alternatif untuk menyajikan karya yang berada di area publik untuk dapat menarik perhatian pengunjung agar mengunjungi galeri (lihat Gambar 11).

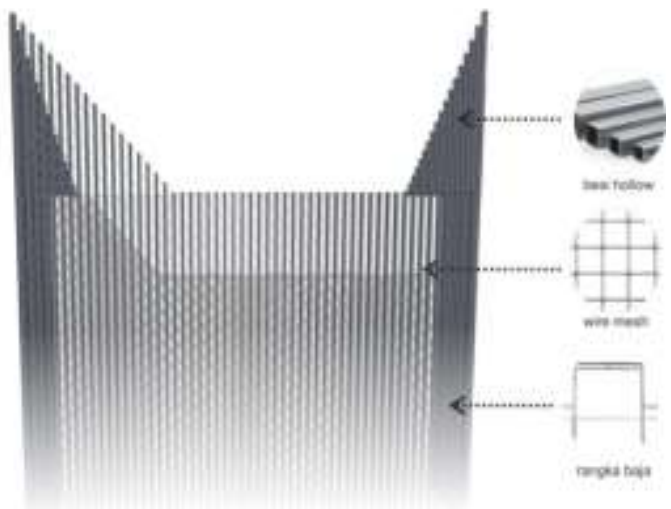

Gambar 11. Fasad Bangunan Galeri
Penggunaan material dengan warnawarna yang netral untuk menunjang penyajian karya dan karakter ruang yang dibutuhkan di mana setiap elemen pembentuk ruang dapat digunakan sebagai

media maupun background untuk karya (lihat Tabel 1).

Tabel 1. Material dan Penerapan pada Ruang

\begin{tabular}{|l|l|l|l|}
\hline Material & Warna & Gambar & Penerapan \\
\hline $\begin{array}{l}\text { Acian } \\
\text { semen }\end{array}$ & $\begin{array}{l}\text { Abu- } \\
\text { abu }\end{array}$ & $\begin{array}{l}\text { Lantai } \\
\text { ruang-ruang } \\
\text { pamer. }\end{array}$ \\
\hline Cat putih & Putih & $\begin{array}{l}\text { Dinding, } \\
\text { plafon } \\
\text { ruang-ruang } \\
\text { pamer }\end{array}$ \\
\hline
\end{tabular}

\subsection{Analisis Struktur Atap dan Badan}

1. Tujuan: menentukan struktur badan dan atap yang dapat menunjang fungsi bangunan.

2. Pertimbangan: fleksibel, dimensi dan penyajian karya, bentuk bangunan

3. Hasil analisis: ruang pamer yang direncanakan terdiri dari ruang pamer tetap dan temporer dimana ruang pamer temporer cenderung lebih fleksibel. Berdasarkan pemahaman tersebut dan pertimbangan sebelumnya, ruang pamer tetap menggunakan modul kolom 7-8m, sedangkan ruang pamer tetap didesain bebas kolom pada tengah ruang dengan perkuatan pada kolom dan balok.

Struktur atap pada massa utama yang merupakan ruang pamer menggunakan struktur space frame (rangka baja ringan) dengan penutup Aluminium Composite Panel (ACP) sehingga memungkinkan ruang-ruang pamer pada lantai atas juga dapat bebas kolom. Sedangkan pada massa penunjang menggunakan atap datar yang dapat digunakan untuk ruang pameran di area outdoor (lihat Gambar 12). 
4. KESIMPULAN (KONSEP DESAIN)

Dari hasil analisis serta keterkaitan dari beberapa data di atas, maka diperoleh hasil berupa desain Galeri Seni Rupa Kiwari di Surakarta sebagai berikut:

Nama : Galeri Seni Rupa Kiwari

Lokasi : Jl. Diponegoro

Luas Lahan $\quad: 5.335 \mathrm{~m}^{2}$

Luas Bangunan: $6.624 \mathrm{~m}^{2}$

Jumlah Lantai : 4 lantai

Daya Tampung : 470 orang

Dalam menjawab tuntutan berbagai bentuk seni rupa kiwari yang diwadahi, maka pada bangunan galeri ini disediakan ruang-ruang pamer dengan skala yang bervariasi, berbentuk persegi, dan dengan karakter ruang yang cenderung netral tanpa ornamentasi (lihat Gambar 14,15,16,17), penempatan open space pada tapak untuk mengakomodasi karya-karya yang dipamerkan di luar ruang (lihat Gambar 2,12,13), penggunaan dinding partisi geser dan grid ceiling pada ruang-ruang pamer (lihat Gambar 3,4,16,17), pengamatan vertikal pada ruang pamer (lihat Gambar 14,16), fasad bangunan yang juga dapat dimanfaatkan sebagai media penyajian karya (lihat Gambar 11,12).

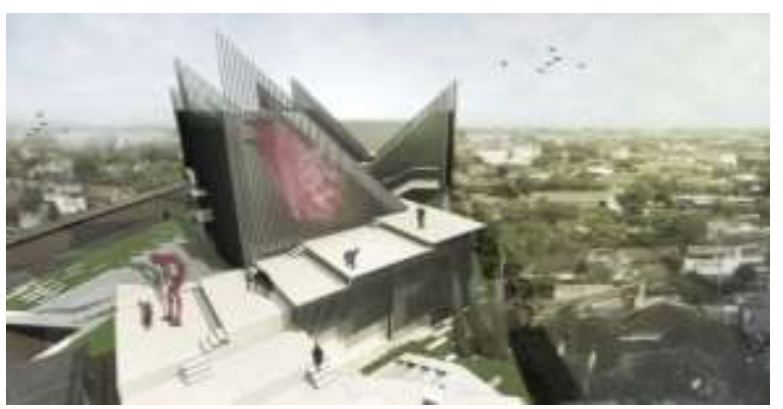

Gambar 12. Eksterior Galeri

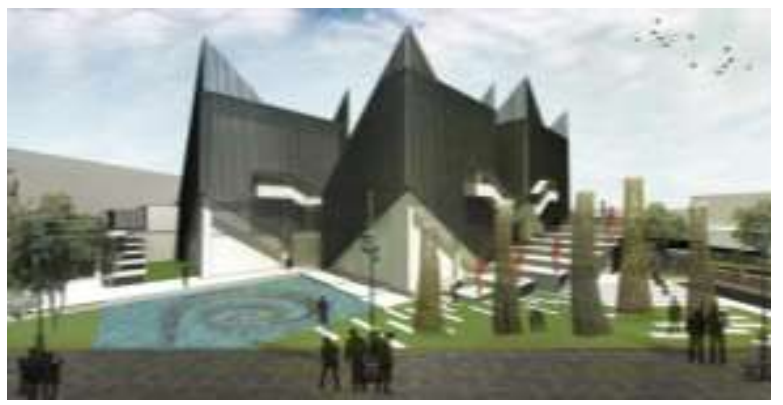

Gambar 13. Eksterior Galeri

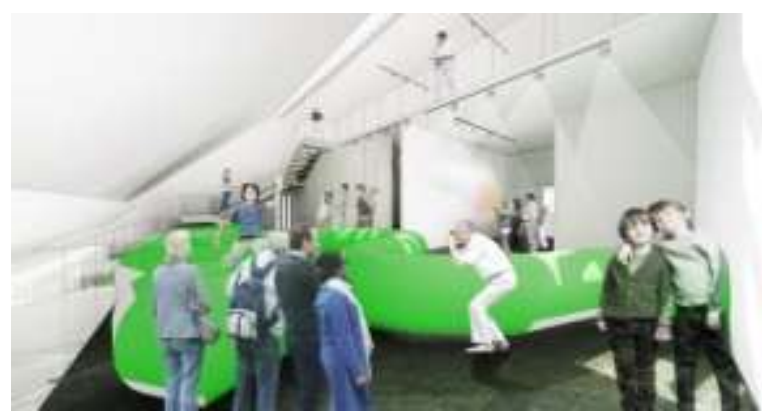

Gambar 14. Interior Ruang Pamer Tetap Lantai 3 dan 4

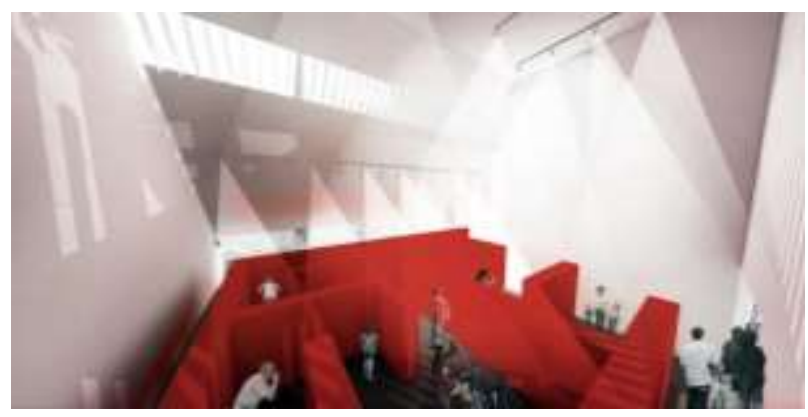

Gambar 15. Interior Ruang Pamer Temporer Lantai 3

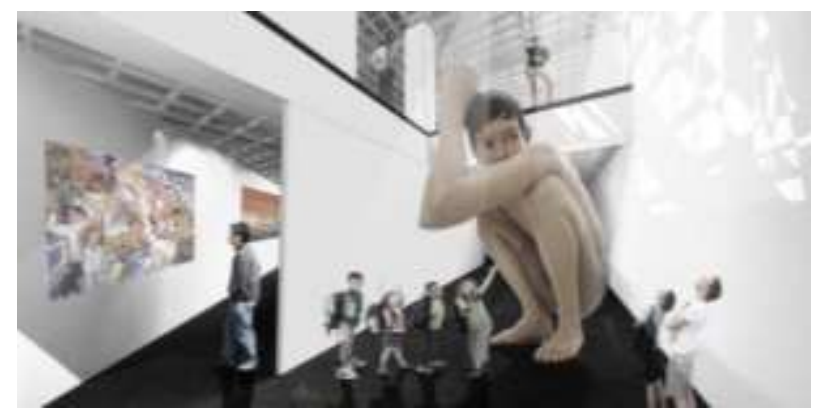

Gambar 16. Interior Ruang Pamer Tetap Lantai 1

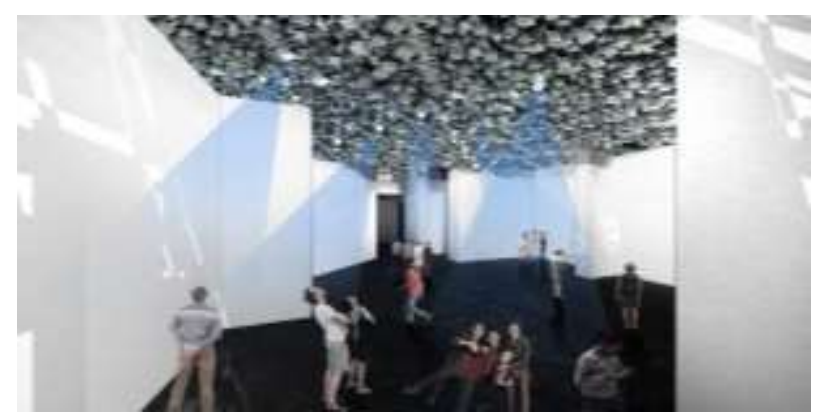

Gambar 17. Interior Ruang Pamer Temporer Lantai 1 


\section{REFERENSI}

Chiara, Joseph dkk. 2001. Time Saver Standart for Building Type. Singapura : McGraw-Hill.

Lim, William S. Warren dan Tan Hock Beng. 1998. The New Asian Architecture.: Vernacular Traditions and Contemporary Style. Hongkong : Periplus Editions.

Susanto, Mikke. 2012. Dosen Versus Mahasiswa. Tersedia : http://mikkesusanto.jogjanews.com/ (18 Maret 2015). 